This is an Open Access version of the article: Jacob, M., Annys, S., Frankl, A., De Ridder, M., Beeckman, H., Guyassa, E., Nyssen, J., 2015. Tree line dynamics in the tropical African highlands - identifying drivers and dynamics. Journal of Vegetation Science, 26 (9), 9-20. DOI: 10.1111/jvs.12215

\title{
Treeline dynamics in the tropical African highlands - identifying drivers and dynamics
}

\author{
Miro Jacob, Sofie Annys, Amaury Frankl, Maaike De Ridder, Hans Beeckman, Etefa Guyassa \& \\ Jan Nyssen
}

Jacob, M. (corresponding author, Miro.Jacob@ugent.be), Annys, S. (Sofie.Annys@ugent.be),

Frankl, A. (Amaury.Frankl@ugent.be), Guyassa, E. (etefag@yahoo.com) \& Nyssen, J.

(Jan.Nyssen@ugent.be): Department of Geography, Ghent University, Krijgslaan 281 S8, 9000, Gent, Belgium

Beeckman H. (hans.beeckman@africamuseum.be): Royal Museum for Central Africa, Laboratory for Wood Biology and Xylarium, Leuvensesteenweg 13, 8030, Tervuren, Belgium

Guyassa, E.: Department of Land Resource and Environmental Protection, Mekelle University, Mekelle, Ethiopia

\section{Abstract}

Questions: What are the potential drivers of treeline change in the tropical African highlands? Are the temperature sensitive treelines in these highlands shifting as a result of climate change?

Significance: The high altitude forests provide important ecosystem services for the vulnerable environment of the tropical highlands. Climate change is expected to have pronounced effects on the treeline limit of these forests. Afro-alpine tropical treelines are therefore potentially valuable as a proxy of climate change and the related response of ecosystems in the tropical highlands.

Location: Tropical African highlands

Results: The influence of the climatic factors in the African tropical highlands is significantly different compared to other regions. The potentially determining factors for treeline distribution in tropical Africa are temperature, precipitation and cloudiness, carbon balance, fire and anthropo-zoogenic impacts. Despite recent temperature increase, treelines have not risen to higher altitudes in the tropical African highlands. Instead, high human pressure has caused stabilization and even recession of the treelines below their natural climatic limit, particularly through livestock herding. But, even neglecting human pressure, there might be a lag in response time between temperature and treeline change.

Conclusions: The actual drivers of treeline change in the African tropical highlands are mainly fire and anthropogenic pressure rather than climate change. But, long-term drought periods can be a trigger for fire induced deforestation of the treeline vegetation. Additionally, in volcanic active mountains, is volcanic activity also a potentially limiting factor for the treeline distribution. Treeline dynamics can thus not be used as a proxy of climate change for the African tropical highlands. 
Keywords: Anthropogenic impact; tropical afroalpine highlands; ericaceous belt; climate change

\section{Introduction}

42

Alpine treelines mark the transition between mountain and alpine environments on high mountain slopes (Berdanier 2010) and are one of the most apparent vegetation boundaries worldwide (Körner \& Paulsen 2004; Berdanier 2010). According to Callaghan et al. (2002) and Holtmeier (2009), the shift from dense montane forests to treeless alpine grasses and shrubs is characterized by increasing stand fragmentation and stuntedness. This transition is called the treeline ecotone (Fig. 1a). There are three frequently used terminologies which refer to the transition from forest to non-forest stages (Fig. 1b) (Körner \& Paulsen 2004; Van Bogaert et al. 2011): (i) the 'timberline', i.e. the boundary of the closed forest, (ii) the 'tree species limit', i.e. the boundary formed by the upper individuals of tree species, regardless of the growth form, and (iii) the 'treeline', i.e. the upper limit of forest patches characterized by a growth height of more than $3 \mathrm{~m}$, or $2 \mathrm{~m}$ in absence of snow accumulation as is the case in the tropics (Holtmeier 2009). Trees from the Ericoideae subfamily form the upper treeline forest in the tropical African mountains (Wesche et al. 2000).

The first systematic treeline studies occurred approximately 150 years ago, as reviewed in Marek (1910). At present, knowledge on the ecophysical situation of treelines in the tropics is still fragmental (Bader 2007; Holtmeier 2009). Tree growth is constrained by changing environmental conditions with increasing altitude (Körner 2012). This makes the altitudinal tree-limit potentially responsive to climate change (Körner \& Paulsen 2004). This is illustrated by a lowering of the treelines in tropical Africa during the dry and cold Last Glacial Maximum (LGM) and by rising treelines in the Holocene as a result of temperature increase (Wu et al. 2007). Atmospheric $\mathrm{CO}_{2}$ concentrations are higher since the start of the Holocene, which caused a switch from rainfall limited treelines in the LGM to temperature limited treelines in the Holocene (Wu et al. 2007).

There are few continuous long-term climate reconstructions available that focus on the African tropics. Among the first, Thompson et al. (2002) reconstructed the Holocene climatic history in Africa from an ice core of the Kilimanjaro ice fields. Evidence was given for three periods of abrupt climatic shifts and predicted complete melting of the Kilimanjaro ice 
 \\ INSERT FIGURE 1}

fields by 2015-2020 (Thompson et al. 2002). The IPCC (2007) stated that 'warming of the climate system is unequivocal, as is now evident from observations of increases in global average air and ocean temperatures, widespread melting of snow and ice and rising global average sea level'. The temperature rise of the past century is most prominent and rapid at high altitudes and latitudes IPCC (2007).

The tropical African mountains are hotspots in biodiversity, comprising a high amount of endemic species that have their habitat in these mountains. A substantial reduction, shift and extinction of African flora and fauna species is expected in diverse African ecosystems (IPCC 2007). Species that reproduce slowly, disperse poorly, and are isolated are most vulnerable to climate warming (McNeely et al. 1990). The mountain-restricted species of the African highlands are good examples of such isolated species, which are highly sensitive to environmental stress (IPCC 2007). The value of forests on mountain slopes is much wider than only for biodiversity. High mountain forests are important for slope stability and regionally important as a hygric buffer providing water for downstream sources and for agriculture in the surrounding lowlands (Miehe \& Miehe 1994; Price 2003). The climate controlled tree limit of these mountain forests forms a clearly visible ecotone worldwide. Afro-alpine tropical treelines are therefore considered to be a potential proxy of climate change (Bader 2007). Evidence for this is given by LGM treeline oscillations due to past climate change in the afro-alpine mountains (Wu et al. 2007). The associated counterpart of treeline shifts are shifts in the altitudinal range of grass- and shrubland. Such shifts increase the risk of species extinctions and can impede the provision of important non-forest ecosystem services. Understanding the drivers of treeline dynamics in the tropics is important to understand dynamics and spatial patterns of vegetation at the treeline (Bader 2007). It is important to understand the dynamics that are taking place, in order to develop sustainable conservation strategies (Burgess et al. 2007).

The aim of this paper is to identify the potential drivers of treeline change in the tropical African highlands mountains and to answer the question whether temperature sensitive treelines in these mountains are shifting as a result of climate change. This will also allow to evaluate if treeline shifts can serve as a proxy of climate change in tropical Africa. 


\subsection{Study Area}

***INSERT FIGURE 2 highlands environments (table 1).

Previously studied African tropical mountains with summits ranging above the present tropical treeline elevation $(3300-4000 \mathrm{~m})$ were selected for this paper (Fig. 2). These mountains are: Rwenzori Mountains (5109 m), Virguna Mountains (4507 m), Simen Mountains (4550 m), Bale Mountains (4377 m), Mount Elgon (4321 m), Mount Kilimanjaro (5896 m), Mount Kenya (5199 m), and Mount Cameroon (4095 m). For all these mountains, the upper treeline ecotone is formed by trees from the Ericoideae subfamily dominated by the genus Erica L. (Miehe \& Miehe 1994; Wesche et al. 2000). Treeline forests are prominent above $3000 \mathrm{~m}$ in most tropical African mountains and grow over an elevation range of up to 1000 m (Miehe \& Miehe 1994); described by Hedberg (1951) as the 'ericaceous belt'. Beyond this elevation, tree growth is not possible and afroalpine scrubs dominate in the landscape. Erica L. trees are small (ca. $8 \mathrm{~m}$ ) and have needle-like scleromorphic leaves. Afroalpine scrubs are dominated by species of Alchemilla and Helichrysum (Bussmann 2006). Anthropo-zoogenic impact strongly modified the vertical extent of the ericaceous belt by woodcutting, fire and grazing. But despite the limited area still covered by ericaceous forest at the high altitude tree limit, this forest type remains vital for the regional environment of the tropical African highlands (Miehe \& Miehe 1994).

\section{Biophysical and anthropo-zoogenic constraints for tree growth in the tropical African}

The elevation of the treeline is limited by local and global environmental and anthropo-zoogenic constraints, which cause trees to reach their limit at a certain elevation and prevent tree growth above that limit (Wieser \& Tausz 2007; Körner 2012). The biological limit is caused by severe habitat stress, which is limiting metabolism, development and reproduction of the trees. At a global scale there are evident differences in the impact of these constrains between the tropical highlands and the boreal and temperate 
The elevation of the treeline in the tropics is determined by a combination of

136 biophysical factors. Of which, low ambient temperature is a key factor regulating growth,

137 regeneration and survival of trees at the treeline (Körner 1998; Holtmeier 2009; Harsch et al.

138 2009). The seasonal mean temperature at the treeline varies from 6 to $8^{\circ} \mathrm{C}$ outside the 139 tropics and around $5^{\circ} \mathrm{C}$ in the tropics (Körner 2012).

140 The limiting factor of growth in the tropics is mainly caused by the permanent stress 141 resulting from the pronounced temperature fluctuation between day and night (Wardle \& 142 Coleman 1992; Miehe \& Miehe 1994; Bader 2007). This is because high intensities of solar 143 radiation can be reached at tropical alpine treelines during the day, due to the low latitude 144 and high altitude, while night frost can occur during every night (Bader 2007). Because of the 145 tropical diurnal climate variability, it is important to differentiate the soil temperature 146 regime in the tropics from that outside the tropics (Holtmeier 2009). In the tropics, mean 147 temperature should be considered a rough indicator only, since there is a large variation in 148 site-specific temperature cycles (Miehe \& Miehe 1994). An annual mean soil temperature of $1496.1 \pm 0.7^{\circ} \mathrm{C}$ was found to correspond with the upper tree limit all year round in the tropics 150 (Hoch \& Körner 2003).

151 While snowfall and snow accumulation at treeline elevations is common outside the 152 tropics, this is rare in the tropics (Sarmiento 1986; Smith \& Young 1987). High seasonal 153 rainfall variability with cold, cloudy and wet seasons alternating with long droughts at the 154 treeline are common in the African tropical highlands, both having a negative impact on tree 155 growth at the treeline (Smith \& Young 1987). Increasing precipitation and cloudiness at the 156 treeline elevation reduces solar radiation for photosynthesis and reduces temperatures and 157 thus limits tree growth (Wieser \& Tausz 2007). On the other hand, water stress due to long 158 term drought impedes seedling establishment during the growing season and reduces the 159 resilience of the vegetation against fire (Körner 2012). Outside the tropics, winter 160 desiccation caused by long-term frost drought is one of the main constraints for tree growth 161 in high mountains (Wieser \& Tausz 2007). Hygric and thermal differences caused by 162 differences in cloudiness are considered more important as controlling factors than 163 exposure effects for the treeline elevation in the tropics (Sarmiento 1986).

164 Freezing is generally less severe and frost damage can occur all year round at the 165 tropical treeline (Smith 1974; Goldstein et al. 1994). Diurnal differences are especially high in 
the dry season, when clear skies prevail (Sarmiento 1986). Physiological adaptations for frost resistance must therefore be permanent in tropical highlands (Sarmiento 1986).

The partial $\mathrm{CO}_{2}$ pressure is lower at high elevations at all latitudes. Treeline vegetation is therefore potentially responsive to increased atmospheric $\mathrm{CO}_{2}$ pressure (Smith et al. 2009). However, Hoch and Körner (2012) studied carbon reserves of treeline trees worldwide and did not find evidence of carbon shortage. Similar results were found in single mountain ranges by Piper et al. (2006) and Shi et al. (2008). This increasingly favours the growth limit hypothesis over the traditional carbon balance hypothesis (Hoch \& Körner 2012; Simard et al. 2013). However, there is another potential effect of elevated $\mathrm{CO}_{2}$ in the tropics, caused by the different response of C4 tropical grasses and C3 woody vegetation to elevated $\mathrm{CO}_{2}$ pressure; $\mathrm{C} 3$ vegetation is competitively favoured (Ziska 2008).

Wind speed and direction are controlled by the local topography. In general, wind speeds at treeline elevation in the tropics are lower than in extratropical mountains (Holtmeier 2009). Evidence is given by giant groundsels and lobelias of several meters high above the treeline in the tropics (Hedberg 1964). The influence of wind is very important to site conditions of temperate and boreal treeline ecotones; especially in the winter season when the treeline is affected by wind-driven snow relocation and abrasion by ice particles (Holtmeier 2009). In addition there exist many local constraining factors, such as the mass elevation effect of mountain ranges or topography effects or differences caused by the soil properties.

Beside these environmental constraints, the treeline elevation is also limited by anthropo-zoogenic influences. Human induced land use and land cover changes are the main drivers of forest cover loss (Kidane et al. 2012), controlled by the continuous pressure for new farmland and firewood (Burgess et al. 2007). Based upon research in Ethiopia (Simen and Bale Mountains) and Uganda (Rwenzori Range and Mount Elgon), Wesche et al. (2000) concluded that fire is an important factor influencing the treeline in East Africa. Natural fires are caused by lightening, but the majority of fires in tropical mountains are human-caused (Hedberg 1964). Multiple reasons exist for human ignited fires. For example, in the Bale Mountains, fire is used to improve the grazing conditions.

Effects of herbivores on the treeline structure and position are globally observed (Cairns \& Moen 2004). The negative effects of herbivores on the treeline are primarily caused by livestock. In the agricultural system of the tropical highlands, livestock plays a key 
198 role as provider of energy, food, fertilizer and status (Nyssen et al. 2004). Livestock browsing impedes regeneration of Erica and other trees of the sub-alpine zone through foliage consumption, trampling and seed predation (Castro et al. 2004).

\section{The potential drivers of treeline change}

The potential drivers of treeline change are the biophysical and anthropo-zoogenic constraints, outlined above, which have recently significantly changed and thus had a potential impact on the elevation of the treeline limit.

\subsection{Temperature increase}

Hulme et al. (2001) studied air temperature patterns in Africa over the last 100 years and found that temperature in the African continent rose with $0.5^{\circ} \mathrm{C}$. In the mountains of East Africa, temperature increased with $0.3^{\circ} \mathrm{C}$ since 1980 (Fig. 3a). According to the A1Bscenario of the Intergovernmental Panel on Climate Change (IPCC) the temperature in the tropics will increase with $3.3^{\circ} \mathrm{C}$ by 2100 (IPCC 2007). The A1B model takes into account a rapid economic growth, a global population peak in the mid-century followed by a decline, a rapid introduction of new more sustainable technologies and a switch to balanced fossil and non-fossil energy sources (IPCC 2007). The scenarios neglecting mitigating policy actions, even project an increase of up to $4.9^{\circ} \mathrm{C}$ (IPCC 2007). Vegetation belts have to adapt to these increasing temperatures, as a result temperature sensitive species may disperse to new habitats (Wright et al. 2009). In the high altitude tropical mountains, these new temperature refuges are relatively nearby and can be accessed by migration upwards the mountain until the growth limit is again reached (Wright et al. 2009).

Körner (2012) has calculated that an increase of $1^{\circ} \mathrm{C}$ would correspond with an increase in elevation of the treeline with 186 meter. This is a general prediction on a worldwide scale, taking only temperature into account. Other factors such as the tree species sensitivity or site specific conditions (e.g. topography, inter-specific competition, moisture availability, etc.) are not included (Chambers et al. 1998; Holtmeier 2009). The altitudinal temperature lapse rate of East Africa is $0.6^{\circ} \mathrm{C}$ per 100 meter elevation (Peyron et al. 2000). A marked temperature increase of $0.3^{\circ} \mathrm{C}$ since 1980 (Hulme et al. 2001) would thus theoretically correspond with an upwards treeline shift of 50 meter; and the IPCC projection of $3.3^{\circ} \mathrm{C}$ by 2100 with an upwards shift of 550 meter (taking only temperature in account). 


\subsection{Rainfall variability}

232 On a global scale, an average temperature rise of $5^{\circ} \mathrm{C}$ by 2100 , would result in a drastic 233 decrease in annual precipitation and soil moisture by $20 \%$ (Schiermeier 2008). However, the 234 high interannual rainfall variability makes it difficult to identify rainfall trends for Africa. 235 According to Hulme et al. (2001), there is a relatively stable regime in East Africa with some 236 evidence of long-term wetting. In contrast, for West Africa and the Gulf of Guinea there has 237 been a pronounced decrease in rainfall. The scenarios of de Wit \& Stankiewicz (2006) predict 238 an increase of rainfall up to $10 \%$ and even $20 \%$ by 2100 for all tropical mountains (Fig. 3b). 239 Climatic wetter conditions for East Africa under global warming are predicted by most 240 climatic models (Lanckriet et al. 2012). Hulme et al. (2001) predict a spreading trend for the 241 equatorial zone of East Africa, where rainfall is expected to increase by 5 to $30 \%$ in 242 December-February, but to decrease by 5 to $10 \%$ in June-August

243 The impact of these changes on the treeline limit is difficult to predict. Increased 244 rainfall and a better spread of rainfall throughout the year decreases water stress and thus enhances tree growth at the treeline. But, this will at the same time increase cloudiness and indirectly decreases the air temperature.

$* * *$ INSERT FIGURE 3

\subsection{Change in carbon balance}

The atmospheric $\mathrm{CO}_{2}$ level rose from pre-industrial $285 \mu \mathrm{mol} \mathrm{I}^{-1}$ (600 gigatonnes (Gt)) to the current level of $384 \mathrm{\mu mol} \mathrm{I}^{-1}(800 \mathrm{Gt}$ ) and is predicted to rise to $1000 \mathrm{Gt}$ by 2050 (IPCC 2007). The main focus of increased $\mathrm{CO}_{2}$ concentrations, due to anthropogenic intensification,

254 is on the likely effect on global mean surface temperature rise. But there are also direct effects on plant growth and physiology, independent of the climatic effect (Ziska 2008). This effect of elevated $\mathrm{CO}_{2}$ concentrations is different for $\mathrm{C}_{3}, \mathrm{C}_{4}$ and Crassulacean Acid Metabolism (CAM) plant species. The widespread $C_{3}$ plants and CAM plants show a significant positive response, while $\mathrm{C}_{4}$ plants exhibit a negative response (Reddy et al. 2010).

259 The negative effect on $\mathrm{C}_{4}$ plants of increased $\mathrm{CO}_{2}$ concentrations is by reduced stomatal conductance and transpiration, which causes higher leaf temperatures and increased drought stress (Bernacchi et al. 2007). 
At treeline elevation in the tropics, the vegetation boundary between afroalpine woodland and grasses correspond with the boundary between $C_{4}$ and $C_{3}$ plants, respectively.

264 Elevated $\mathrm{CO}_{2}$ concentrations in the tropics would thus potentially support the advance of the $265 \mathrm{C}_{3}$ woody vegetation to higher elevations in competition to $\mathrm{C}_{4}$ tropical grasses (Leakey et al. 2009). But more research is necessary for a better understanding of this different $\mathrm{CO}_{2}$ response and the linkage with other environmental factors (Leakey et al. 2009).

\subsection{Anthropo-zoogenic impact}

The global population will grow annually with on average $1 \%$ over the period 2010 2025, which correspond to a population increase of 1.2 billion people in 15 years (UNdata 2013). A growing proportion of the global population will be living in Africa, as the population in Africa is growing very fast (up to $3 \%$ annually) (Fig. 4, FAO 2007). The associated growing population and livestock pressure will further increase environmental pressure in the tropical highlands (Burgess et al. 2007). The impact is already visible through increased, wood cutting and uprooting of Erica stumps, inhibiting tree regeneration (Bishaw 2001).

***INSERT FIGURE 4

\section{Current position and dynamics of the treeline in the African tropical highlands}

The potential response of treelines to climate warming is currently studied worldwide (Holtmeier \& Broll 2007). Harsch et al. (2009) analysed a global dataset of 166 treeline sites; advancing treelines were recorded in $52 \%$ of the sites and in only $1 \%$ there was a recession of the treeline. There is an association between treeline advance and temperature increase, although the mechanisms are not always straightforward. However, the analysis of Harsch et al. (2009) almost completely lacks study sites in the tropics; there are only four tropical sites included of which none are in Africa. This is because little is known about treeline dynamics in the tropical highlands of Africa (Körner 2012). A global representation of the latitudinal position of treelines is given by Körner (1998), showing a strong relation between treeline altitude and latitude in the temperate zone and a maximum in the subtropics. But no significant changes of the treeline position with altitude over a $50^{\circ}$ range around the equator (Körner 1998). This graph again illustrates that treeline data is limited in the tropical and 
294 southern regions. The treeline elevation of the tropical African mountain ranges studied in 295 this paper are therefore included in the Körner (1998) graph in figure 5b; the tropical African 296 treeline elevation is, although scattered, following the general trendline found by Körner 297 (1998). The current understanding of treeline dynamics in Africa are compiled in an overview 298 below and summarized in Table 2.

*** INSERT TABLE 2

\subsection{Shoulders of the Ethiopian Rift Valley}

The Simen Mountains (4543 m) are situated in the northern highlands of Ethiopia and are protected under national legislation since 1969. The Simen Mountains have a unimodal precipitation regime, which is relatively dry compared to the bimodal precipitation regime of the more southern tropical African mountains (Hurni \& Stähli 1982). The treeline formed by Erica arborea lies at an average altitude of 3715 m (Hurni \& Stähli 1982). Shifting of this treeline has been observed by repeat photography at Nebir Mekemacha, which shows an increase of the treeline of approximately $120 \mathrm{~m}$ from 4000 to $4120 \mathrm{~m}$ between 1967 and 1997 (Fig. 5) (Nievergelt et al. 1998; Wesche et al. 2000). There are two possible explanations for this treeline shift: recent climate change and reduced human and livestock pressure. Evidence against the climatic change hypothesis is given by individual Erica trees high above the treeline already in 1968 (Nievergelt et al. 1998). The impact of cattle grazing, woodcutting and burning reduced since the National Park was installed (Wesche et al. 2000).

The treeline in the Bale Mountains $(4400 \mathrm{~m})$ in southern Ethiopia is formed by Erica trimera, which is the dominant species from 3400 up to $4000 \mathrm{~m}$ (Fig. 5). Outliers of individual

317 Erica species are even observed up to $4200 \mathrm{~m}$ (Miehe \& Miehe 1994). These individuals have 318 a mat-like structure as a result of strong eastern winds (Holtmeier 2009). Although that the 319 Bale Mountains are also protected since 1969, the upper treeline of the Bale Mountains is 320 lowered by recurrent fires at many places, to maintain or extend the grazing area (Wesche et 321 al. 2000). As a result, mosaics of forests scrubs and afroalpine grasslands prevail at the treeline in the Bale highlands (Bussmann 2006).

In both mountain ranges is the treeline located at $4000 \mathrm{~m}$, ca. 400-500 meters below 324 the highest summit (Fig. 5). There is thus a potential impact of the summit syndrome described by Körner (2012). But, observations of recent treeline increase in the Simen 
Mountains give evidence against the influence of the summit effect at the current treeline elevation.

\subsection{West Africa}

The climate of Mount Cameroon (4095 m) is extremely moist with up to $10000 \mathrm{~mm}$ annual rainfall at lower elevations and $2000 \mathrm{~mm}$ at the summit (Bussmann 2006). Although the western slopes receive more rainfall, this is not reflected in the vegetation profile. The ericaceous specie Erica mannii, Agauria salicifolia and Myrica arborea form the patchy high altitude treeline ecotone (Bussmann 2006). The abrupt treeline at $3500 \mathrm{~m}$ (Fig. 5) is controlled by periodic volcanic activity, which influences the tree limit directly by destroying existing forest through lava flows and fire and indirectly by unequal deposition of fertile volcanic ashes (Proctor et al. 2007). As a result, the treeline is depressed below its climatic limit (Bussmann 2006). In addition, there is also a high anthropo-zoogenic pressure through woodcutting, fire and livestock browsing, since the population density is almost twice the average of that in sub-Saharan Africa (Burgess et al. 2007).

\subsection{Mountain ranges along the Eastern Rift Valley}

The Erica excelsa treeline at Mount Elgon (4321 m) lies on average at $3300 \mathrm{~m}$ and rises up to $3450 \mathrm{~m}$ in the humid valleys (Wesche 2003; Holtmeier 2009). Despite the negative effects of waterlogging and cold air accumulation, trees grow better in the valleys due to protection from frequent fires. The highest stands in the valleys even occur at $3950 \mathrm{~m}$ (Hamilton \& Perrot 1981; Wesche 2003). The vegetation is, on average every 7-10 year, exposed to high-altitude droughts and thus severe desiccation stress. The impact of drought stress is striking, with up to $50 \%$ of the leaves dying, but the plant phenology is little affected (Wesche 2003). However, the striking consequence of these drought conditions is fire. More than half of the Erica and afro-alpine vegetation was burned during the extremely dry conditions of 1997 (Wesche et al. 2000). Extensive burning caused large scale replacement of woody vegetation by grasslands, which recover much faster. As a result of fire and anthropogenic impact by pastoralists the present treeline is depressed below the climatic tree limit (Fig. 5) (Hamilton \& Perrot 1981; Wesche 2003).

On Mount Kenya (5199 m), the current boundary between the lower alpine zone and upper Erica forest is situated at ca. 3400 m (Fig. 5) (Bussmann 2006). The poorly developed 
Ericaceous forest belt is formed by remnant stands of Erica excelsa, Erica trimera and Erica arborea (Bussmann 2006). The warmer moister climate of the Holocene enabled the treeline 360 to rise in comparison to LGM levels (Rucina et al. 2009). However, the position of the 361 treeline is currently under high anthropogenic pressure, which is marked by increased fire 362 frequency. This has locally resulted in a transition to open vegetation (Bussmann 2006; 363 Rucina et al. 2009). The presence of the plant species Asteraceae Stoebe kilimandscharica and Protea kilimascharicaoften at the treeline, indicate this regular disturbance by high altitude fires. As a result of this disturbances the boundary between the ericaceous belt and the afroalpine grasses is formed by a patchy mosaic rather than a clear altitudinal boundary (Bussmann 2006).

The ericaceous belt of Mount Kilimanjaro $(5895 \mathrm{~m}$ ) is formed by Erica excelsa forest prevailing above $3000 \mathrm{~m}$, with remnants of Erica trimera growing above $3700 \mathrm{~m}$ (Hemp 2009). The treeline is situated at ca. 3800 m, which is below its natural limit (Fig. 5) (Hemp 2005; Körner 2012). In 1976 the treeline reached the 4100 m elevation limit (Hemp 2009). The cause of the treeline lowering with several hundred meters since 1976 is a drier climate, which caused an increased frequency and intensity of fires on the slopes of the Kilimanjaro (Hemp 2005). Precipitation has decreased over 30\% in the recent years, in particular over the last three decades. More frequent and intensive fires have not only lowered the treeline position, but even caused a deforestation of one third of the Kilimanjaro forest in the last 70 years (Hemp 2005).

\subsection{Albertine Western Rift and Congo Nile Crestline} current vegetation zonation.

The Rwenzori Mountains (5109 m) are well preserved from anthropogenic influences. There are fires, but these are comparatively small (Wesche et al. 2000). This makes the Rwenzori Mountains one of the most intact Ericaceous vegetation belts of the African tropical highlands (Wesche et al. 2000). The Erica forest dominated by Erica arborea follows immediately after the bamboo belt (at $3000 \mathrm{~m}$ ) and marks the treeline at $3900 \mathrm{~m}$ (Fig. 5) (Livingstone 1967; Bussmann 2006). Although the eastern slopes are drier, this is not reflected in the vegetation profile (Bussmann 2006). 
The Virunga Mountains (4507 m) are formed by eight adjacent volcanoes. On the 391 highest peak of Mount Karisimbi the treeline is situated at by average $3800 \mathrm{~m}$. On the drier 392 Mount Muhabura $(4127 \mathrm{~m}$ ) trees are only growing up to $3600 \mathrm{~m}$ (Fig. 5). In the Virguna 393 volcanoes the treeline is formed by Erica arborea forest, growing above the Hagenia 394 abyssinica and Hypericum revolutum forest (Bussmann 2006).

\section{INSERT FIGURE 5}

\section{Discussion and conclusion}

The discussion is structured according to the two main questions of this paper: (i) understanding the driving factors determining treeline elevation limits and (ii) identifying treeline dynamics in the African tropical highlands.

402

(i) What are the driving factors determining the treeline elevation in the African tropical highlands?

At present climate change is unequivocal and caused global warming and changing rainfall patterns. These changes have the potential to influence the altitudinal tree growth limit. Unlike in temperate and boreal regions, wind, frost damage and snow accumulation are less important in controlling the treeline position. Treeline species in the tropical highlands must be particularly adapted to high diurnal temperature variation. A temperature increase of $3.3^{\circ} \mathrm{C}$ by 2100 would correspond with an increase of the tropical African treeline

411 by 550 meter, using the vertical temperature lapse rate of East Africa from Peyron et al. 412 (2000) (only taking temperature in account). But, past increases in population pressure in 413 the tropical highlands have depressed the treeline elevation below its climatic limit. Anthropo-zoogenic influences disturb the treeline, mainly by man-made fire to clear the forest for grazing land. The impact of these fires is locally intensified as a result of long term drought, which decreases the resilience of the environment to fire disturbances. Beside this is volcanic activity also a locally important constraint of high altitude tree growth.

\section{(i) Are treelines in the African tropical highlands subjected to change?}

Hedberg (1951) presented a general classification of the vegetation belts of the Eastern African Mountains. He recognized three belts on each mountain: the alpine, the 
ericaceous and the montane forest belts. The treeline is situated in between the alpine and ericaceous belt with an elevation limit between 3550 and 4100 m (Hedberg 1951). This $4100 \mathrm{~m}$-limit corresponds with the treeline in the Simen Mountains at present. The Simen Mountains are the only mountain range in this study of which the treeline rose locally. This indicates that here, the tropical treeline lies below its potential climatic limit (Miehe \& Miehe 1994; Kessler 1995; Bader 2007). A tentative explanation is that the Simen Mountains are located most northern and thus closer to the subtropics and as a result receive less rainfall and cloudiness, which can cause the treeline to rise higher (Körner 2012). But this explanation is too simplistic, because decreasing human impact after national park establishment should also be taken into account.

However, the general trend is that treelines were moved down due to high anthropozoogenic pressure and especially fire (Miehe \& Miehe 1994; Kessler 1995; Ellenberg 1996; Wesche et al. 2000; Hemp \& Beck 2001; Bader 2007). This is the case for most of the mountain ranges studied. In the Bale Mountains, Mount Elgon, Mount Cameroon and Mount Kenya, the treeline is lowered due to high anthropogenic pressure. In addition, on Mount Cameroon volcanic activities have also had a negative effect on the treeline elevation. Disturbance by human and livestock is controlling the treeline elevation at elevations below their natural climatic limit in many African tropical mountain ranges. In the Rwenzori and Virguna Mountains the human pressure is lower because of the politic instability in this region. As a result is the treeline elevation potentially more stable. Yet, little is known about potential vegetation shift in this region. When neglecting human interference, treelines in the tropical African highlands might rise to higher elevations. This is witnessed in the Simen Mountains, although decreasing pasture and wood cutting also played a major role here. $\mathrm{A}$ hypothetical upper treeline limit at $4100 \mathrm{~m}$ is suggested by Hedberg (1951). The $4100 \mathrm{~m}$-limit as suggested by Hedberg (1951) used to be also corresponding with the limit at the Kilimanjaro in 1976. But due to climatic drier conditions in combination with growing anthropogenic pressure is the treeline of the Kilimanjaro also lowered. The effect of decreasing rainfall conditions is thus opposite between the Simen Mountains and the Kilimanjaro.

Overall, treelines in the African tropics are strongly disturbed by human and livestock pressure, which makes it not possible to use them as a proxy of climate change in the tropics. The general trend of a depressed treeline below the climatic limit in the tropical 
454 African highlands favours the hypothesis that treelines are still moving upwards from lower 455 positions due to a slow response time to climate change (Wardle \& Coleman 1992; 456 Holtmeier 1994). Because shifts in species distributions may lag behind climate changes 457 (Dullinger et al. 2012). But evidence against this hypothesis is given by past higher treeline 458 elevations and by evidence of a rising treeline in the Simen Mountains.

(iii) Outline for future work

Overall, more treeline research in the African tropical highlands is vital to improve the 462 scientific understanding of the response of high altitude tropical treelines to environmental 463 changes. In the global treeline research of Harsch et al. (2009), continental Africa is a blank 464 spot on the map. The IPCC has recognized this need to understand the ecosystem dynamics 465 and climate variability in Africa. Climate change may have important effects on the 466 functioning of the ecosystems of the African tropical highland. A better understanding of this 467 can help to make realistic predictions, which are important as an input to land management 468 scenarios.

469

\section{Acknowledgments}

471 This research was financially supported by the Belgian Special Research Fund (BOF fund, 472 Ghent University). We sincerely thank Gebrekidan Mesfin and Silke Broidioi for their 473 assistance. We also express our thanks for the valuable inputs of the editor and the 474 anonymous reviewers. 
Bader, M.Y. 2007. Tropical alpine treelines: how ecological processes control vegetation patterning and dynamics. Wageningen University, Wageningen.

Berdanier, A. 2010. Global Treeline Position. Nature Education Knowledge 3: 11-19.

Bernacchi, C.J., Kimball, B. a, Quarles, D.R., Long, S.P., \& Ort, D.R. 2007. Decreases in stomatal conductance of soybean under open-air elevation of $\mathrm{CO} 2$ are closely coupled with decreases in ecosystem evapotranspiration. Plant physiology 143: 134-44.

Bishaw, B. 2001. Deforestation and Land Degredation in the Ethiopian Highlands: A Strategy for Physical Recovery. Northeast African Studies 8: 7-25.

Van Bogaert, R., Haneca, K., Hoogesteger, J., Jonasson, C., De Dapper, M., \& Callaghan, T.V. 2011. A century of tree line changes in sub-Arctic Sweden shows local and regional variability and only a minor influence of 20th century climate warming. Journal of Biogeography 38: 907-921.

Burgess, N., Balmford, a, Cordeiro, N., Fjeldsa, J., Kuper, W., Rahbek, C., Sanderson, E., Scharlemann, J., Sommer, J., \& Williams, P. 2007. Correlations among species distributions, human density and human infrastructure across the high biodiversity tropical mountains of Africa. Biological Conservation 134: 164-177.

Bussmann, R.W. 2006. Vegetation zonation and nomenclature of African Mountains - An overview. Lyonia 11: 41-66.

Cairns, D.M., \& Moen, J. 2004. Herbivory influences tree lines. Journal of Ecology 92: 10191024.

Callaghan, T.V., Werkman, B.R., \& Crawford, R.M. 2002. The Tundra-Taiga interface and its dynamics: concepts and applications. Ambio 12: 6-14.

Castro, J., Zamora, R., Hódar, J.A., \& Gómez, J.M. 2004. Seedling establishment of a boreal tree species ( Pinus sylvestris ) at its southernmost distribution limit : Journal of Ecology 92: 266-277.

Chambers, J.Q., Higuchi, N., \& Schimel, J.P. 1998. Ancient trees in Amazonia. Nature 391: $135-136$.

Dullinger, S., Willner, W., Plutzar, C., Englisch, T., Schratt-Ehrendorfer, L., Moser, D., Ertl, S., Essl, F., \& Niklfeld, H. 2012. Post-glacial migration lag restricts range filling of plants in the European Alps. Global Ecology and Biogeography 21: 829-840.

Ellenberg, H. 1996. Páramos und Punas der hochanden Südamerikas, heure großenteils als potentielle Wälder anerkannt. Verhandlungen der Gesellschaft für ökologie 25: 17-23. 
FAO. 2007. State of the world's forest. Rome.

Gehrig-Fasel, J., Guisan, A., \& Zimmermann, N.E. 2008. Evaluating thermal treeline indicators based on air and soil temperature using an air-to-soil temperature transfer model. Ecological Modelling 213: 345-355.

Gehrig-Fasel, J., Guisan, A., \& Zimmermann, N. 2007. Tree line shifts in the Swiss Alps : Climate change or land abandonment ? Journal of Vegetation Science 18: 571-582.

Goldstein, G., Meinzer, F.C., \& Rada, F. 1994. Environmental biology of a tropical treeline specie, Polylepis sericea. In Rundel, P.W., Smith, A.P., \& Meinzer, F.P. (eds.), Tropical Alpine Environments: plant form and function, Cambridge University Press, Cambridge.

Hamilton, A.C., \& Perrot, R.A. 1981. A study of altitudinal zonation in the montane forest belt of Mt. Elgon, Kenya/Uganda. Vegetatio 45: 107-125.

Harsch, M. a, Hulme, P.E., McGlone, M.S., \& Duncan, R.P. 2009. Are treelines advancing? A global meta-analysis of treeline response to climate warming. Ecology letters 12: 10409.

Hedberg, O. 1964. Features of afroalpine plant ecology. Svenska växtgeografiska sällsk, Uppsala.

Hedberg, O. 1951. Vegetation belts of the east African mountains. Svensk Botanisk Tidskrift 45: 140-202.

Hemp, A. 2009. Climate change and its impact on the forests of Kilimanjaro. African Journal of Ecology 47: 3-10.

Hemp, A. 2005. Climate change-driven forest fires marginalize the impact of ice cap wasting on Kilimanjaro. Global Change Biology 11: 1013-1023.

Hemp, A., \& Beck, E. 2001. Erica excelsa as a fire-tolerating component of Mt. Kilimanjaro's forests. Phytocoenologia 47: 3-10.

Hoch, G., \& Körner, C. 2012. Global patterns of mobile carbon stores in trees at the highelevation tree line. Global Ecology and Biogeography 21: 861-871.

Hoch, G., \& Körner, C. 2003. The carbon charging of pines at the climatic treeline: a global comparison. Oecologia 135: 10-21.

Holtmeier, F.K. 1994. Ecological aspects of climatically caused timberlines fluctuations review and outlook. In Beniston, M. (ed.), Mountain environment in changing climates, pp. 220-232. Routledge, Londen and New York.

Holtmeier, F.K. 2009. Mountain timberlines: Ecology, Patchiness and Dynamics (M. Beniston, Ed.). Springer, Havixbeck, Germany. 
Holtmeier, F.K., \& Broll, G. 2007. Treeline advance - driving processes and adverse factors. Landscape Online 1: 1-32.

Hulme, M., Doherty, R., Ngara, T., New, M., \& Lister, D. 2001. African climate change : 1900 2100. 17: 145-168.

Hurni, H., \& Stähli, P. 1982. Simen mountains, Ethiopia: climate and dynamics of altitudinal belts from the last cold period to the present day. Geographisches Institut der Universität Bern, Bern, Switzerland.

IPCC. 2007. Climate Change, the physical science basis. Contribution of working group I to the fourth assessment report of the Intergovernmental Panel on Climate Change.

Kessler, M. 1995. Present and potential distribution of Polylepis (Rosaceae) forests in Bolivia. In Churchill, S.P., Baslev, H., Forero, E., \& Luteyn, J.L. (eds.), Biodiversity and conservation of Neotropical montane forests, pp. 281-294. Proceedings of the neotropical montane forest biodiversity and conservation symposium, New york.

Kidane, Y., Stahlmann, R., \& Beierkuhnlein, C. 2012. Vegetation dynamics, and land use and land cover change in the Bale Mountains, Ethiopia. Environmental monitoring and assessment 184: 7473-89.

Körner, C. 1998. A re-assessment of high elevation treeline positions and their explanation. Oecologia 115: 445-459.

Körner, C. 2012. Alpine treelines - Functional ecology of the global high elevation tree limits. Springer, Basel.

Körner, C., \& Paulsen, J. 2004. A world-wide study of high altitude treeline temperatures. Journal of Biogeography 31: 713-732.

Lanckriet, S., Araya, T., Cornelis, W., Verfaillie, E., Poesen, J., Govaerts, B., Bauer, H., Deckers, J., Haile, M., \& Nyssen, J. 2012. Impact of conservation agriculture on catchment runoff and soil loss under changing climate conditions in May Zeg-zeg (Ethiopia). Journal of Hydrology 475: 336-349.

Leakey, A.D.B., Ainsworth, E. a, Bernacchi, C.J., Rogers, A., Long, S.P., \& Ort, D.R. 2009. Elevated $\mathrm{CO} 2$ effects on plant carbon, nitrogen, and water relations: six important lessons from FACE. Journal of experimental botany 60: 2859-76.

Livingstone, D.A. 1967. Postglacial vegetation of the Ruwenzori Mountains in Equatorial Africa. Journal of experimental botany 37: 25-52.

Marek, R. 1910. Waldgrenzstudien in den österreichischen Alpen. Petermanns Geographische Mitteilungen, Ergänzungsheft

McNeely, J.A., Miller, K.R., Reid, W. V., Mittermeier, R.A., \& Werner, T.B. 1990. Conserving the world's biological diversity. 
Miehe, G., \& Miehe, S. 1994. Ericaceous Forests and Heathlands in the Bale Mountains of South Ethopia - Ecology and man's Impact. Stiftung Walderhaltung in Afrika, Hamburg.

Nievergelt, B., Good, T., \& Güttinger, R. 1998. A survey of the flora and fauna of the Simen Mountains National Park. Walia (special issue), Zürich.

Nyssen, J., Poesen, J., Moeyersons, J., Deckers, J., Haile, M., \& Lang, A. 2004. Human impact on the environment in the Ethiopian and Eritrean highlands-a state of the art. EarthScience Reviews 64: 273-320.

Peyron, O., Jolly, D., Bonnefille, R., Vincens, A., Guiot, J. 2000. Climate of East Africa $6000{ }^{14} \mathrm{C}$ Yr B.P. as inferred from Pollen Data. Quaternary Research 54: 90-101.

Piper, F.I., Cavieres, L. a., Reyes-Díaz, M., \& Corcuera, L.J. 2006. Carbon sink limitation and frost tolerance control performance of the tree Kageneckia angustifolia D. Don (Rosaceae) at the treeline in central Chile. Plant Ecology 185: 29-39.

Price, M.F. 2003. Why mountain forests are important. The forestry chronicle 79: 1998-2001.

Proctor, J., Edwards, I.D., Payton, R.W., \& Nagy, L. 2007. Zonation of forest vegetation and soils of Mount Cameroon, West Africa. Plant Ecology 192: 251-269.

Reddy, A.R., Rasineni, G.K., \& Raghavendra, A.S. 2010. The impact of global elevated CO 2 concentration on photosynthesis and plant. Current Science 99: 46-57.

Rucina, S.M., Muiruri, V.M., Kinyanjui, R.N., McGuiness, K., \& Marchant, R. 2009. Late Quaternary vegetation and fire dynamics on Mount Kenya. Palaeoecology 283: 1-14.

Sarmiento, G. 1986. Ecological features pf climate in high tropical mountains. Oxford University press, Oxford.

Schiermeier, Q. 2008. The long summer begins. Nature 454: 266-269.

Shi, P., Körner, C., \& Hoch, G. 2008. A test of the growth-limitation theory for alpine tree line formation in evergreen and deciduous taxa of the eastern Himalayas. Functional Ecology 22: 213-220.

Simard, S., Giovannelli, A., Treydte, K., Traversi, M.L., King, G.M., Frank, D., \& Fonti, P. 2013. Intra-annual dynamics of non-structural carbohydrates in the cambium of mature conifer trees reflects radial growth demands. Tree physiology 33: 913-23.

Smith, A.P. 1974. Bud temperature in relation to Nyctinastic leaf movement in an Andean Giant Rosette plant. Biotropica 6: 263-265.

Smith, W.K., Germino, M.J., Johnson, D.M., \& Reinhardt, K. 2009. The Altitude of Alpine Treeline: A Bellwether of Climate Change Effects. The Botanical Review 75: 163-190. 
Smith, A.P., \& Young, T.P. 1987. Tropical alpine ecology. Annual Review of Ecology and Systematics 18: 137-158.

Thompson, L.G., Mosley-Thompson, E., Davis, M.E., Henderson, K. a, Brecher, H.H., Zagorodnov, V.S., Mashiotta, T. a, Lin, P.-N., Mikhalenko, V.N., Hardy, D.R., \& Beer, J. 2002. Kilimanjaro ice core records: evidence of holocene climate change in tropical Africa. Science 298: 589-93.

UNdata. 2013. United Nations Statistics Division of the Department of Economics and Social Affairs.

Wardle, P., \& Coleman, M.C. 1992. Evidence for rising upper limits of four native New Zeeland forest trees. New Zealand Journal of Botanica 30: 303-314.

Wesche, K. 2003. The importance of occasional droughts for afroalpine landscape ecology. Journal of Tropical Ecology 19: 197-208.

Wesche, K., Miehe, G., \& Kaeppeli, M. 2000. The Significance of Fire for Afroalpine Ericaceous Vegetation. Mountain Research and Development 20: 340-347.

Wieser, G., \& Tausz, M. 2007. Current Concepts for Treelife Limitation at the Upper Timberline. In Trees at their upper limit: treelife limitation at the Alpine Timberline, pp. 1-18. Springer, Dordrecht.

De Wit, M., \& Stankiewicz, J. 2006. Changes in surface water supply across Africa with predicted climate change. Science 311: 1917-21.

Wright, S.J., Muller-Landau, H.C., \& Schipper, J. 2009. The future of tropical species on a warmer planet. Conservation Biology 23: 1418-26.

Wu, H., Guiot, J., Brewer, S., Guo, Z., \& Peng, C. 2007. Dominant factors controlling glacial and interglacial variations in the treeline elevation in tropical Africa. Proceedings of the National Academy of Sciences of the United States of America 104: 9720-4.

Ziska, L.H. 2008. Controversies in Science Rising Atmospheric Carbon Dioxide and Plant Biology : The Overlooked Paradigm. DNA and Cell Biology 27: 165-172.

(1) 
637 Table 1: A comparison of potential environmental constraints for tree growth at the treeline

638 between the tropical and the boreal and temperate zones ${ }^{\mathrm{a}}$

\begin{tabular}{lll}
\hline Factor & Tropics & Boreal and temperate zone \\
\hline Air temperature & Mean seasonal temperature: $5^{\circ} \mathrm{C}$ & Mean seasonal temperature: $6-8^{\circ} \mathrm{C}$ \\
& $\begin{array}{l}\text { Diurnal fluctuation } \\
\text { Strong solar radiation }\end{array}$ & $\begin{array}{l}\text { Length of the growing season } \\
\text { Less strong solar radiation }\end{array}$ \\
Soil temperature & Diurnal variation & Seasonal variation \\
Precipitation and cloudiness & Mean temperature: $6.1 \pm 0.7^{\circ} \mathrm{C}$ & Permafrost \\
& High seasonal rainfall variability & Snowfall accumulation \\
& Cloudiness differences & Winter desiccation \\
Frost damage & Lower influence: permanent & Critical factor: high influence \\
& adaptations & \\
Carbon balance & $\mathrm{C}_{3} / \mathrm{C}_{4}$ balance & C vegetation \\
Wind & Gentle wind: low influence & Stronger wind: high influence \\
& & Snow relocation; wind-driven abrasion \\
Local factors & Site specific & Site specific \\
Anthropo-zoogenic pressure & Very high influence & Lower influence \\
\hline
\end{tabular}

${ }^{\mathrm{a}}$ The factors are described and fully referenced in the text.

639

640 
641 Table 2: Treeline dynamics and driving processes in the Tropical Highlands of Africa

642

\begin{tabular}{|c|c|c|c|c|c|c|}
\hline Mountain range & Latitude & Elevation & Treeline $^{a}$ & Trend & Cause & Source \\
\hline Simen Mountains & $13^{\circ} 14^{\prime} \mathrm{N}$ & 4543 & 4000 & Upward & $\begin{array}{l}\text { Decrease in anthropogenic } \\
\text { pressure }\end{array}$ & $\begin{array}{l}\text { Hurni \& Stähli } \\
\text { (1982); Wesche et } \\
\text { al. (2000) }\end{array}$ \\
\hline Bale Mountains & $06^{\circ} 49^{\prime} \mathrm{N}$ & 4377 & 4000 & Downward & Anthropogenic pressure: fire & $\begin{array}{l}\text { Miehe \& Miehe } \\
\text { (1994); Wesche et } \\
\text { al. (2000) }\end{array}$ \\
\hline Mount Cameroon & $04^{\circ} 13^{\prime} \mathrm{N}$ & 4095 & 3500 & Downward & $\begin{array}{l}\text { Volcanic activity and } \\
\text { anthropogenic pressure }\end{array}$ & Proctor et al. (2007) \\
\hline Mount Elgon & $01^{\circ} 09^{\prime} \mathrm{N}$ & 4321 & 3300 & Downward & $\begin{array}{l}\text { Drought pressure: fire } \\
\text { Anthropogenic pressure }\end{array}$ & $\begin{array}{l}\text { Wesche (2003); } \\
\text { Holtmeier (2009) }\end{array}$ \\
\hline Mount Kenya & $00^{\circ} 08^{\prime} \mathrm{N}$ & 5199 & 3400 & Downward & Anthropogenic pressure: fire & $\begin{array}{l}\text { Bussmann (2006); } \\
\text { Rucina et al. (2009) }\end{array}$ \\
\hline Mount Kilimanjaro & $03^{\circ} 04^{\prime} \mathrm{S}$ & 5895 & 3800 & Downward & Drought pressure: fire & $\begin{array}{l}\text { Hemp (2005); } \\
\text { Körner (2012) }\end{array}$ \\
\hline Rwenzori Mountains & $00^{\circ} 27^{\prime} \mathrm{N}$ & 5109 & 3900 & ? & $\begin{array}{l}\text { Preserved from } \\
\text { anthropogenic pressure }\end{array}$ & $\begin{array}{l}\text { Wesche et al. } \\
\text { (2000); Bussmann } \\
\text { (2006) }\end{array}$ \\
\hline Virunga Mountains ${ }^{b}$ & $01^{\circ} 14^{\prime} \mathrm{S}$ & 4507 & $\begin{array}{l}3800 \\
3600\end{array}$ & ? & $\begin{array}{l}\text { Mount Muhabura: Rainfall } \\
\text { limited? }\end{array}$ & Bussmann (2006) \\
\hline
\end{tabular}

\footnotetext{
${ }^{a}$ Average treeline elevation

${ }^{b}$ The Virunga Mountains: Mount Karisimbi and Mount Muhabura
}

643

644

645

646

647

648

649

650

651

652

653

654

655

656

657

658

659

660 


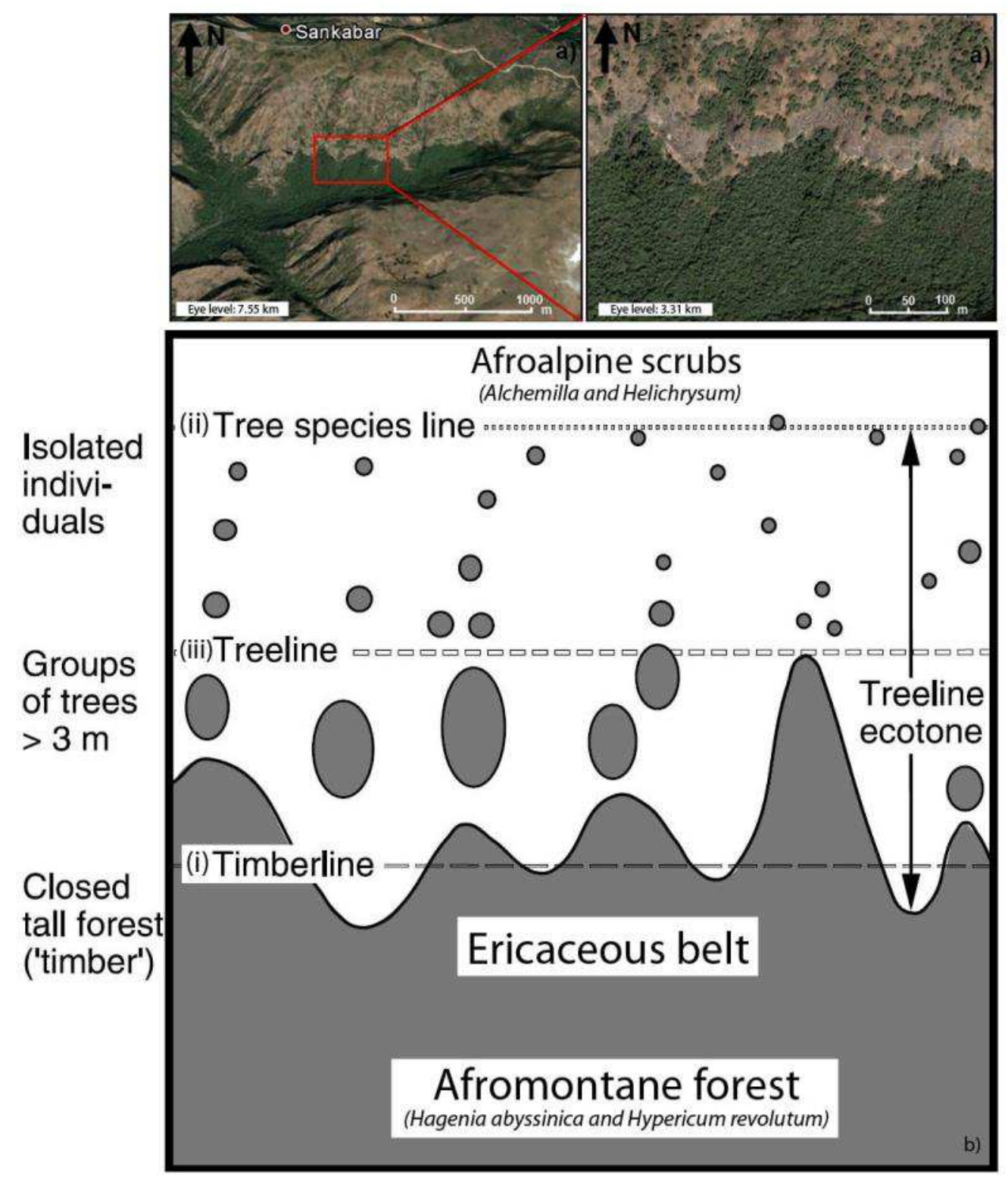

Figure 1: Complexity of the treeline (a) Google Earth Image of the treeline at the Simen Mountains, Sankabar camp $\left(13^{\circ} 14^{\prime} \mathrm{N}, 38^{\circ} 3^{\prime} \mathrm{E}\right)$, visualized at two different scales to emphasize the treeline gradient. (b) The treeline ecotone modified after Körner \& Paulsen (2004) with 


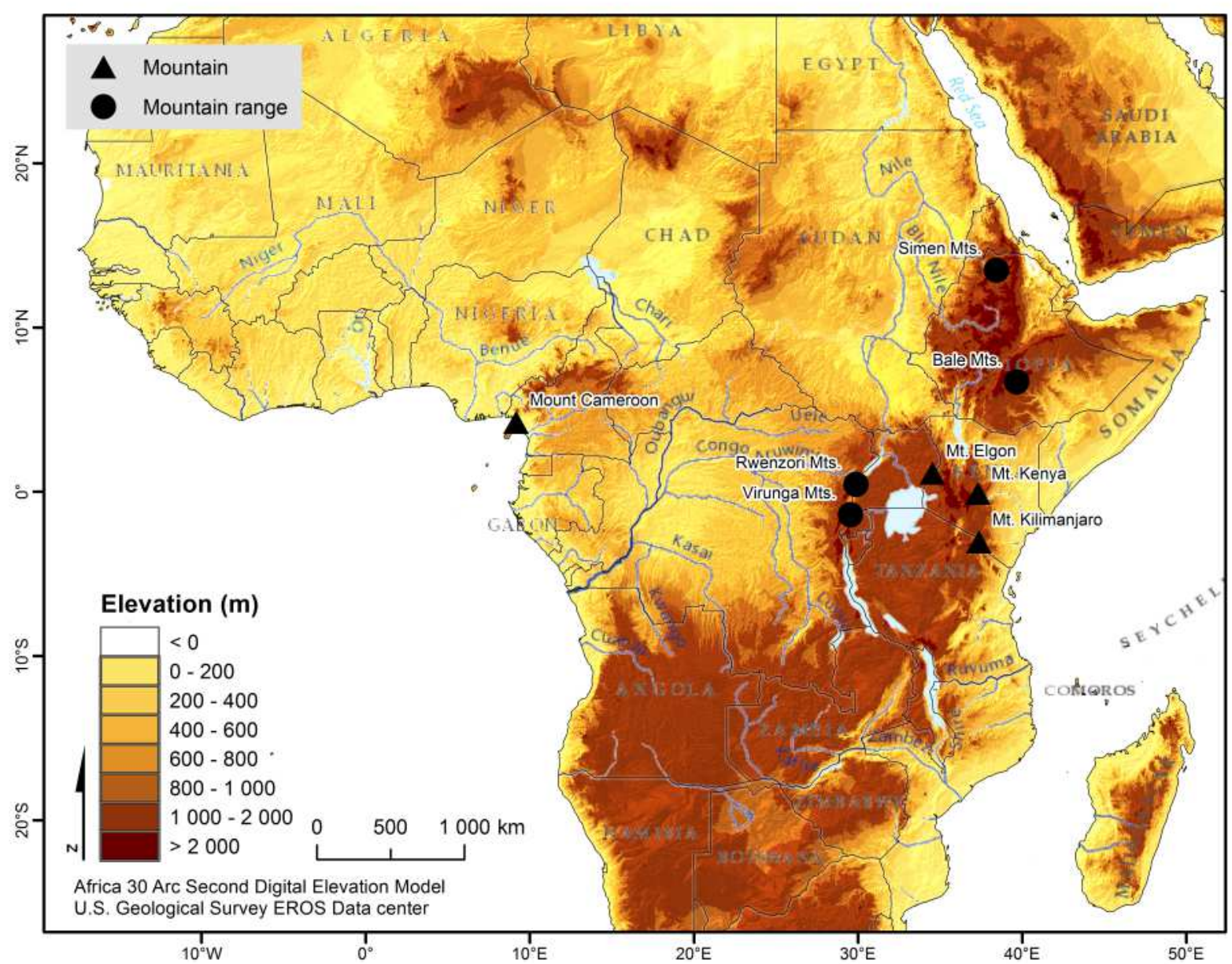

676

677

678

679

680
Figure 2: The studied tropical mountains of Africa that range above the treeline elevation. 

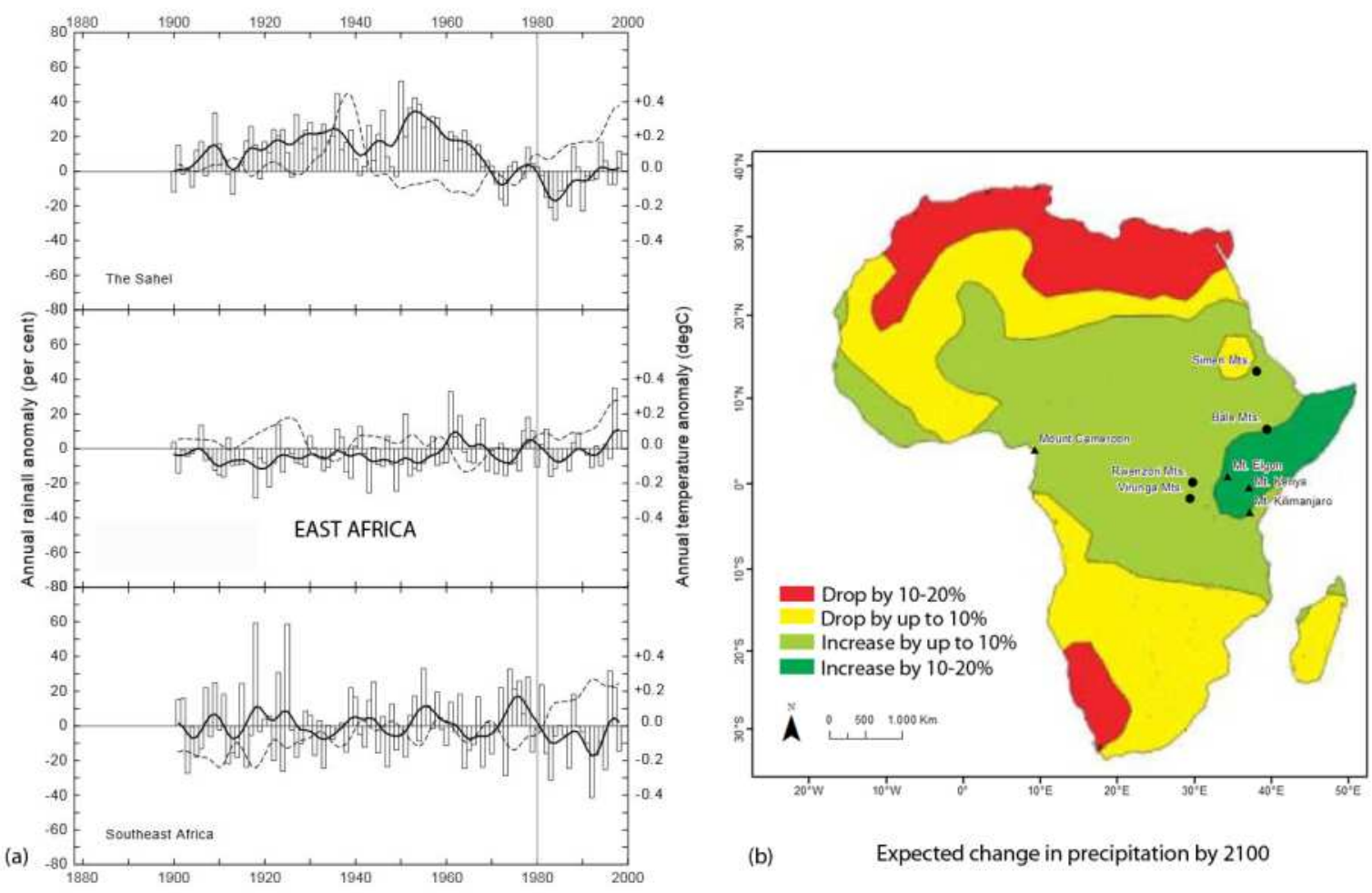

Figure 3: Temperature and rainfall trends in Africa since 1900 (modified after Hulme et al. (2001) and de Wit \& Stankiewicz (2006)): (a) Annual rainfall (histogram and bold line) and mean temperature (dashed line) anomalies for the period 1900-1998, with the 1961-1990 average as reference. The trend is given for three African regions, of which East Africa is best corresponding with the tropical African mountain regions. Note, the temperature increase after 1980 (indicated by a vertical line); (b) expected change in precipitation by the end of the 21st century for Africa. Note, the long term wetting trend in East Africa. 


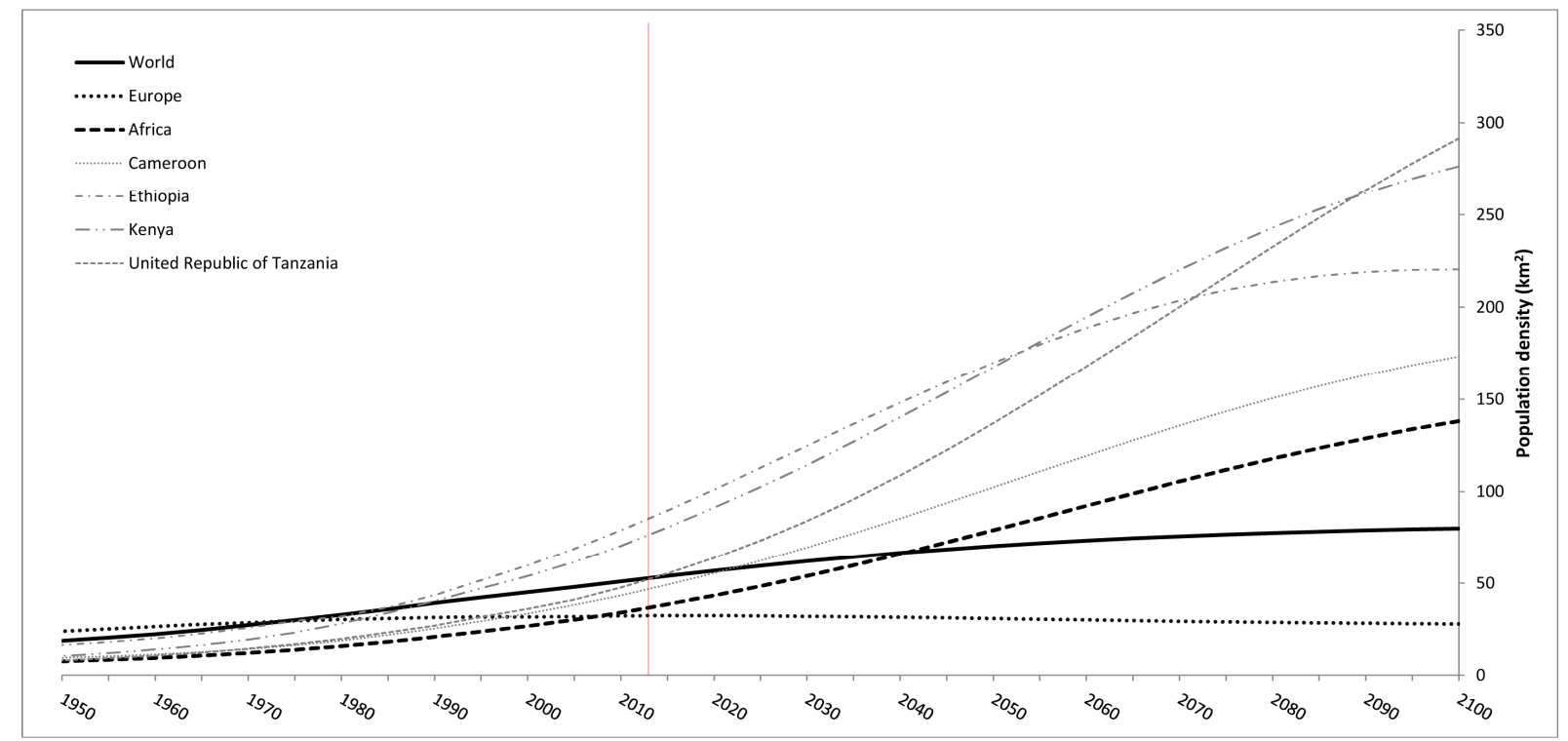

Figure 4: Population dynamics in the tropical African highlands: (a) Population density, (b) growth rate. The situation of 2013 is indicated with a red vertical line. 


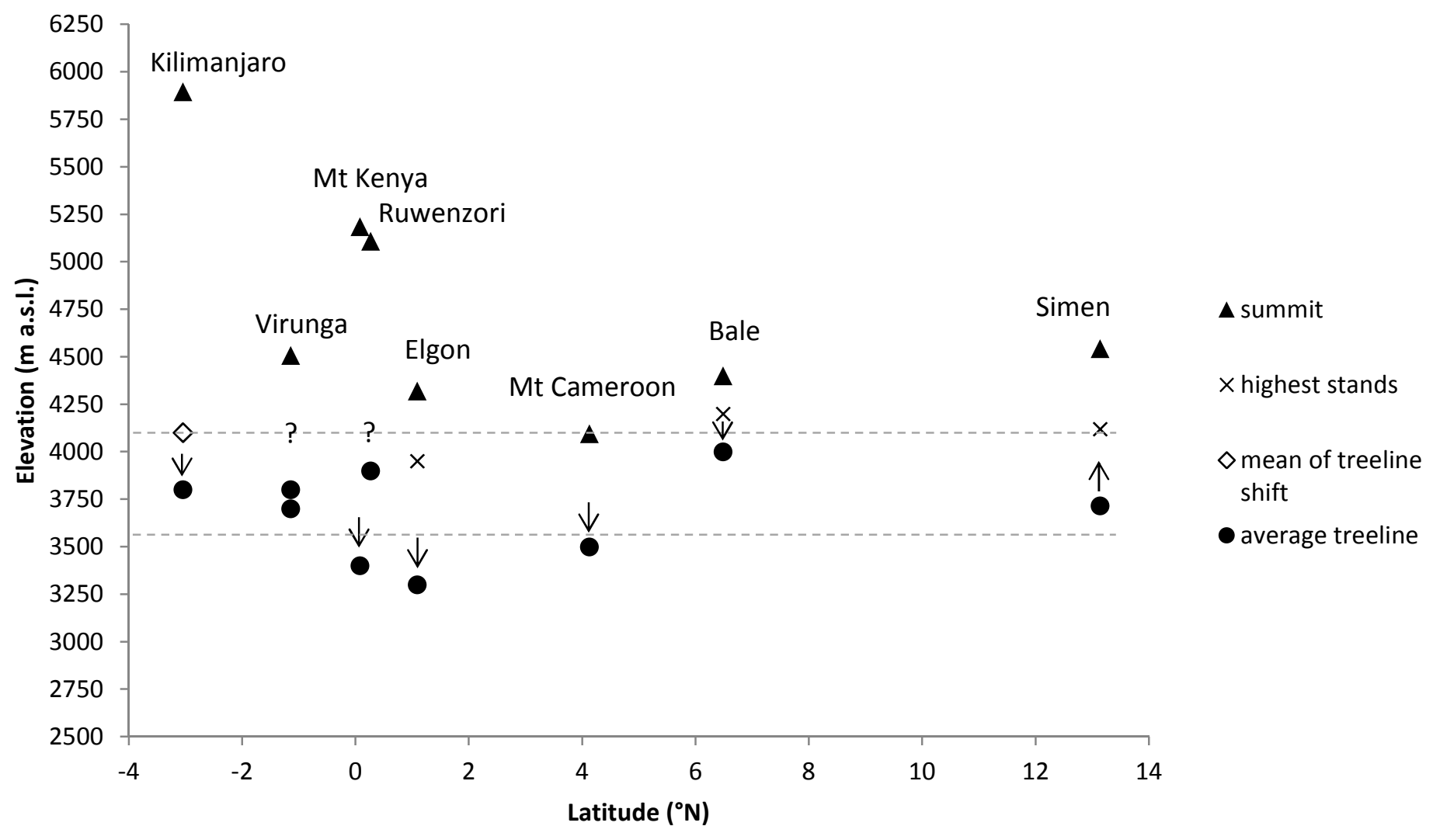

763

764

765

766

767

768
Figure 5: Synthesis of treeline dynamics in the tropical African highlands (see table 2 for references). Arrows indicate the treeline trend. The zone between the dashed lines refers to the upper treeline limit zone described by Hedberg (1951). 
Final paper available at: http://onlinelibrary.wiley.com/doi/10.1111/jvs.12215/full 